\title{
DRAMATIZING SARTREAN BAD FAITH AND HEIDEGGERIAN AUTHENTICITY: AN ANALYSIS OF CONTRASTING POSITIONS IN RELATION TO THESE IDEAS IN THREE FILM NARRATIVES-SHADOWS AND FOG, MIDNIGHT IN PARIS AND MAGIC IN THE MOONLIGHT
}

\author{
Andreas Treki Dohtdong $1 \llbracket$ (iD) \\ ${ }^{1}$ Research Scholar, English Department, North-Eastern Hill University, Shillong-793022, East Khasi Hills, \\ Meghalaya, India
}

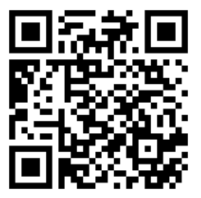

Received 02 November 2021

Accepted 21 January 2022

Published 17 February 2022

\section{CorrespondingAuthor}

Andreas Treki Dohtdong, andreastrekidohtdong@gmail.com

\section{DOI}

10.29121/shodhkosh.v3.i1.2022.73

Funding: This research received no specific grant from any funding agency in the public, commercial, or not-for-profit sectors.

Copyright: (C) 2022 The Author(s). This is an open access article distributed under the terms of the Creative Commons Attribution License, which permits unrestricted use, distribution, and reproduction in any medium, provided the original author and source are credited.

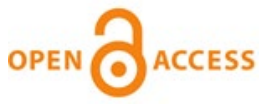

\section{ABSTRACT}

Woody Allen is a well-recognized name in the filmmaking world and his films have garnered considerable critical attention. He is known for writing and directing entertaining and philosophical films. A particular brand of philosophy which is called existentialism is associated with his works. This paper is meant to be a study of this aspect of his work in relation to the idea of magic. Magic has featured in quite a few of his films and while its presence has been noted, its importance in relation to existentialism within his work has not always been studied. There are two central concepts discussed here and these are bad faith and authenticity, which have been propounded by two existentialist thinkers-Jean Paul Sartre and Martin Heidegger. This paper will probe the manner in which all these ideas are combined into a filmic narrative framework by Allen. Three films have been selected since they are very pertinent to the discussion at hand and also because they have not always been viewed in the way that this paper presents. There is an ambiguity regarding Allen's own position in relation to these specific thinkers' ideas. This paper will highlight the manner in which such an ambiguity arises in these films as well as showcase Allen as a serious dramatist in his own right.

Keywords: Magic, Existentialism, Bad Faith, Authenticity, Film

\section{INTRODUCTION}

Woody Allen is one of the most prolific Hollywood filmmakers working right now and his comic genius for portraying characters that embody philosophical ideas has been widely noted. In particular, the influence of existentialist thinkers like Jean Paul Sartre and Martin Heidegger has been noted by Lee (1997). Hence, this paper is devoted to an analysis of Allen's use of magic as a feature in his films in connection with Sartrean bad faith and Heidegger's idea of authenticity. The idea of magical thinking as a form of inauthenticity will be analyzed here. Three films have been selected here for this purpose and these are Shadows and Fog, Midnight in Paris, and Magic in the Moonlight. At first glance, these films do not seem to carry much philosophical significance and hence this paper is meant to shed a light on the way Allen concretely dramatizes the aforementioned philosophical concepts in these film narratives. Certain crucial dialogues in these films which exemplify the literary quality of Allen's films have been considered. 
Flynn (2006). points out that Martin Heidegger's concept of immersion is crucial to his philosophy. Heidegger (2001). in his work Being and Time, uses the terms Das Man and forfeiture to refer to the usual manner in which people exist in their daily lives and he argues that people are normally habituated to forget their existential freedom and the possibilities resulting from it. What is implied is that people are routinely submerged in a sea of demands and that their energies are channelled towards a very narrow set of possibilities. There is the implication that people never fully make conscious choices and instead choose to adopt a herd mentality leaving no room for reflection on the importance of their freedom and death.

Bad faith is usually understood as implying a refusal to acknowledge one's ability to transcend one's identity. Sartre (2003). develops his major concepts in Being and Nothingness which consists of the idea of humans as beings whose nature or identity is never fixed, and they are always endowed with the freedom to choose to remake their identities or moral values. Hence, for Sartre bad faith means the surrender to the anxiety which causes one to submerge oneself under a single identity. Flynn (2006). notes that the idea of bad faith is more popularly understood as a reference to this type of self-deception and that Sartre was concerned in explicating how societies are constructed in a way which fosters such an attitude. However, the idea of bad faith can imply more than what is stated here, and this is certainly the case when we consider the situations in which bad faith can occur. Sartre (2003). himself argues that bad faith can manifest in various ways. There is room for interpretation here and as we shall see that the manner in which bad faith is reflected in the chosen films, while different from Sartre's examples in his book, is very much in line with his major idea.

Sartre (2003) argues that people desire magic as a way of getting out of situations where their attempts at solving their problems do not succeed and especially when no viable solution appears before them. People resort to magical thinking as a solution to quell the frustrations and fear they may have when they meet certain obstacles on their paths. Implied here, is the idea that one not only wishes that the parameters of one's situations be altered, but that one can trick oneself into believing that the laws of nature can be suspended or bent to one's favour. One can be happy with one's life and the nature of one's situation as long as it does not prove to be an obstruction in one's quest for happiness or disturb one's sense of self-contentment. For example, imagine a situation where a person goes to a supposed clairvoyant or psychic with the idea of enquiring about the future prospects. The point which needs to be emphasized here is not the person's curiosity. This enquiry can result from the person's dissatisfaction with the present and the psychic gives him encouragement that the future can be glimpsed with the hope that something can be done to change things.

\section{OBJECTIVES}

The paper aims at making an existential analysis of the selected films specifically through the use of Sartrean bad faith and Heideggerian concept of authenticity.

The selected films are not usually considered to be as substantial as Allen's other critically acclaimed works. The paper aims to show how Allen is able to write narratives that are thematically complex and that too in very subtle ways. Allen's 
ingenuity as a dramatist to come up with stories that engage with the philosophical ideas mentioned above.

This article also aims to show Allen understanding of Sartre and Heidegger's philosophical positions and his creative response to their ideas.

\section{SIGNIFICANCE OF THE STUDY}

The paper presents a very different view of the selected films, one which elevates them from the common perception that they are lacking in seriousness. The paper also provides a view of how films can be used to present difficult and sophisticated philosophical ideas on screen.

The paper can help the reader to appreciate these films but also to get a better sense of what the aforementioned philosophers are trying to do. Sartre and Heidegger are not easy to understand especially for beginners. This paper can help readers navigate through their philosophy since it deals with fictional but concrete representations of their concepts.

The paper can help equip the reader with certain tools and concepts which they can use to analyse and critique other works of literature and films. Looking for subtleties of meaning in drama can be very difficult and this paper emphasizes the need for a more nuanced analysis of stories in both narrative and visual form.

\section{REVIEW OF LITERATURE}

Apart from the selected films, Sartre's idea of bad faith in his philosophical magnum opus Being and Nothingness is used. Sartrean bad faith is an excellent concept for character analysis and highlighting the flaws in the thought process of characters. Heidegger's concept of authenticity found in his work Being and Time, is also a concept which can be used as a critique of characters and their illusions. Flynn's A Very Short Introduction to Existentialism and J. Reynolds' Understanding Existentialism are critical in understanding the basic themes of existentialist thinkers and the general direction in which their ideas were heading. Lee's book Woody Allen's Angst: Philosophical Commentaries on His Serious Films provides an excellent glimpse of the major themes in Allen's work especially of those released before Midnight in Paris and Magic in the Moonlight. Friedrich Nietzsche's Ecce Homo and The Birth of Tragedy anthologized under the title of Basic Writings of Friedrich Nietzsche are important since Allen alludes to certain ideas within them. Matthew Lucas and Craig Williams' reviews of Allen's films are important since they are reputed film critics, and their perspectives are useful in pointing out what key ideas are missing from their understanding of the selected films.

\section{A CASE FOR BAD FAITH AND INAUTHENTICITY}

Allen (1992) wrote and directed Shadows and Fog which serves as a good example of a film where the ideas mentioned above are dramatized. This film centres on the character of Kleinman who finds himself being targeted by, on the one hand, a murderer on the loose and on the other, the townspeople who mistake him for the killer. At one point in the film Kleinman finds himself in the coroner's examination room and we get the following bit of dialogue: 
Coroner: My interest in all this murder business is entirely scientific.

Klienman: I'm sure. I'm sure.

Coroner: I'm determined to use this opportunity to find out something definitive about the nature of evil. Why is the killer the way he is? Sometimes, certain impulses that can drive an insane man to murder inspire others to highly creative ends. Once I have him here on this table, dismembered and scrutinized in minute detail, then I shall know the answer with certainty to questions that now I can only speculate on.

Klienman: Yeah. But, but it's not possible that under the microscope there's something you could never, see?

Coroner: What are you implying? A spiritual element? A soul that lives on after we're dead. A God? Ask him if there's anything else. (Allen, (1992), 15:10)

Here, it appears that Allen is setting up a debate between the idea that evil or evil deeds can be explained through deterministic causes, and the idea of evil as a creation of human freedom. Essentially, as a member of the audience, one is invited to ponder on this issue in relation to Allen's other films. For example, Allen (1989). in Crimes and Misdemeanours portrays his central character as a being responsible for a murder but then he ends up escaping from the law and any form of human justice by hiding his crimes and effacing his sense of guilt. The killer in Shadows and Fog, like the protagonist in this film, is never apprehended and the coroner is never given a chance to satisfy his scientific curiosity. By not allowing his audience to get an intimate portrait of the killer, one gets the sense that the killer is simply meant to be an embodiment of death and the forces which collude against a person's survival. The killer in this film, unlike in the other one mentioned above, becomes a symbol rather than being merely an actual human character. This scene and in particular the coroner's tone of voice, when he shows Klienman the face of one of the victims, further emphasizes the idea that this particular filmic universe is without an omnipotent and benevolent God. If God is absent or does not come to aid the humans of this world, then there seems to be no protection against the dangers lurking around. In this sense, one can interpret the title of the film as implying this idea that there are always threats against a person's safety hidden everywhere in this town. The characters cannot see clearly where their paths are going to lead them and hence for Kleinman and the town's inhabitants there is a deep sense of insecurity in two ways. First, there is an unknown danger in the form of the killer and secondly, there is the fact of mortality which is known but which cannot be avoided. The film then is not simply about catching the killer, but instead, at a metaphorical level, it is about the fear of death itself.

The connection between the fear of death, magic and bad faith is clearly dramatized towards the end of the film. Klienman is blamed for the murders that have been committed as a result of the failure on the people's part to capture the real killer and the sense of frustration which comes with it. Klienman runs into a circus magician by the name of Almstead who helps him find refuge from the killer through the use of magic. Klienman is magically made to enter a mirror from which he taunts the killer, and the latter then finds himself trapped in a cage and then chained. But the moment the other characters arrive in the scene, the killer escapes and the following bit of exchange takes place between the magician and another man: 
Almstead: No man could have escaped from... Look, look. You see here, these are real the locks.

Man: Almstead, you drink too much.

Klienman: No, he was.

Almstead: I tell you. He was here. We had the killer.

Klienman: Search the building.

Man: Looks like he's a better magician than you. (Allen, (1992), 1:17:22)

There are two important points which can be gleaned from this scene with the first being that death is an inescapable fact. As a writer, Allen refuses to allow any kind of shelter from this harsh truth for his characters. Secondly, by not creating a world where magic fixes everything, Allen does not allow this piece of magic to be taken as anything other than a fantasy. He is arguing against the idea that there can really be a form of magic that would allow people to either escape death or survive its effects. Allen keeps things grounded and this bit of the story only serves to show how much magic is desired but can never be fully achieved. Here, Sartre's point about magic as a way of battling difficulties is well dramatized.

Allen however does not seem to be in complete agreement with Sartre on the manner in which one can deal with the fear of death. In the end, Kleinman makes the decision to join the circus as an assistant to Almstead. This is particularly evident in the following scene:

Kleinman: What better way to... to spend the rest of my life than... than to help you with... with all those wonderful illusions of yours!

Man: It's true. Everybody loves his illusions.

Almstead: Loves them. They need them. Like they need the air. (Allen, (1992) , 1:22:04)

This is where the idea of the soul and the existence of spiritual elements which form a significant part of traditional religions come into play again. If God does not exist or any form of divine entity as implied by the coroner, then one can argue from this ending that such ideas are still needed to stave off the fear of death. For an atheist like Sartre, this construction of such illusions is precisely what he is against. It is not That Sartre is not acknowledging the threat of death. Sartre (2003). notes that death does not allow for life to come to any dignified end and that it can happen at any moment. Death can come out of hiding in the shadows at any moment in the film, which is why Kleinman, and the other characters are searching for protection. The problem here is that there is no divine providence to shelter them from any danger. They are left on their own against forces that are unseen and the fear which arises is too much to bear. The illusions, whatever, they might be, seem to them to be a better alternative than an outright confrontation with mortality.

Allen here seems to be suggesting that perhaps illusions are really the only way to deal with death despite their placebo like effect. Bad faith seems to be the only option to choose here if his characters are to be able to live a happy and contented life. Cowardice is the dominant trait of Kleinman's persona here. Kleinman admits "I can be brave. You know. It's just that I can't think about it first, you know. If I ever think about what's going to happen to me, then I lose control of my muscles" (Allen, (1992) , 1:17:57). From the Sartrean point of view, Klienman's acceptance of his identity as a coward from which he cannot transcend is an act of bad faith. While the 
characters surrounding Kleinman can be said to be braver than him, yet in the face of death, it seems that bravery is not really something that can be useful for all of them. Courage is not going to save these characters from death. But bad faith is what will assuage their fears and help them cope with death. The temporary arrest of the killer represents the idea that bad faith can help them stop thinking about death and pretend that it is not a problem. The title of the film can be understood as suggesting that living underneath the veil of the shadows and fog of magical illusions are what people want and perhaps, they have to.

Heidegger (2001). argues that when one experiences the fear of death, one needs to have a sense of resoluteness. Reynolds (2006). Notes that the battle against the fear of death requires one to enter a Heideggerian state of authenticity which rejects any ideas of God or religion as way of dealing with one's mortality. Klienman's decision to join the circus magician is a choice towards forfeiture and the circus represents a life of immersion. Hence, Kleinman is choosing to enter a state of inauthenticity and committing an existentialist sin. At times, this seems to be the position that Allen (2015). himself is advocating and this is especially the case when he says, during an interview at the Cannes film festival, that despite all the philosophical musings that people do, life is essentially meaningless and in the face of death, the best one can do is to take up distractions. In other words, the best Kleinman can do is to succumb to illusions. Life can be a circus of false ideas for Kleinman, but it can at least make him happy as can be seen from the fact that, prior to the ending, Klienman shows no optimism or enthusiasm but in the end he does.

\section{A CASE AGAINST BAD FAITH AND INAUTHENTICITY}

If Shadows and Fog represents a philosophical stance against Sartre and Heidegger, then in Midnight in Paris, Allen (2011). can be viewed as making a case for the ideas of these two philosophers. This film concerns Gil Pender, a Hollywood screenwriter, who is vacationing in Paris with his fiancé Inez and her parents. On one of the tours, Gil has the following exchange with Inez and her friend Paul:

Inez: He's not actually sure he can write a novel.

Paul: Really?

Inez: I mean honey, so far, your track records, you know in, well, everyone loves your movies.

Gil: Well scripts are easier so.

Inez: Why don't you tell them about the lead character in the book you're working on right now.

Gil: I don't like to discuss my work.

Inez: ... just the character.

Gil: No, no, no.

Inez: Okay, He works in a nostalgia shop.

..

Paul: And just which era would you have preferred to live in, Miniver Cheevy?

Inez: Paris in the twenties ... 
Paul: Nostalgia is denial. Denial of the painful present.

Inez: Oh well, Gil is a complete romantic. I mean, he would be more than happy living in a complete state of perpetual denial.

$\cdots$

Paul: And the name for this fallacy is called Golden Age thinking. (Allen, (2011), 9:54)

The theme of denial and self-deception is again brought up here. Flynn (2006). argues for the existence of a different type of bad faith which consists of dreaming about various possibilities and rejecting the importance of the present. Gil is doing exactly this when he longs to live in a different set of circumstances instead of fully participating in the present. Like the character of Miniver Cheevy in Edwin Arlington Robinson's poem of the same name, he measures his present life to that of the past and finds the present wanting. Miniver Cheevy yearns for a life of adventure like the one he discovered while reading the Arthurian romances and he hates the one he finds himself in. One of the reasons which lead Gil to doubt the artistic value of his work is the fact that he compares it to that of the literary greats of the past. He wishes he could attain the level of achievement that they did. Gil is glamorizing a past which he has never witnessed or experienced. His nostalgia is not of something that belongs to his own life. Gil is wasting is time by living only in his thoughts. Nostalgia is a symptom of bad faith in this context since Gil is not choosing, at this moment, to change his identity as someone who refuses to partake in the present completely. He feels like this is who he is as a person and does not realize that he has the freedom to get out of this psychological problem and fix his life.

Gil's despondence comes to a halt when, for a short period of time, he is magically transported to the Paris of the 1920s, the one which he adores. Allen smoothly creates a link between these two historical periods through the use of a vintage car whose occupants invite Gil to travel with them to a Party one night. In this way, Gil is ferried from the present to the past at certain intervals in the story. Here, he finds himself giddy with excitement when he meets Scott Fitzgerald, Ernest Hemingway, and other artists he admires. Life is bright for Gil, and he finds a new sense of enthusiasm. An important exchange takes place between Gil and Hemingway:

Hemingway: The assignment was to take the hill. There were four of us. Five if you counted Vincente but he had lost his hand when a grenade went off and couldn't fight as he could when I first met him. He was young and brave, and the hill was soggy from days of rain, and it sloped down toward a road and there were many German soldiers on the road and the idea was to aim at the first group and if our aim was true, we could delay them.

Gil: Weren't you scared?

Hemingway: Of what?

Gil: Getting killed.

Hemingway: You'll never write well if you fear dying. Do you?

Gil...It's probably, might be my greatest fear actually.

Hemingway: Well, it's something all men before you have done, and all men will do. (Allen, (2011), 33: 50) 
Allen here is using the popular image of Hemingway as a novelist who drew from his experiences of the First World War to create fiction where a certain type of male characters has come to embody the idea of bravery in the face of death. Even Allen's description of a battle scene above is an imitation of the real Hemingway's writing style. The important point here is that courage or Heidegger's idea of resoluteness is advocated as an antidote to Gil's fears. One gets the sense here that the idea of resoluteness also entails an attitude of stoicism. While Klienman's cowardice and bad faith is not condemned by Allen, he carves a different fate for Gil in this story.

Hemingway persuades Gil to show his own unpublished work to Gertrude Stein and Gil does exactly this with the hope that he would receive some helpful tips. Stein makes the following remarks after reading Gil's work: "We all fear death and question our place in the universe. The artist's job is not to succumb to despair but to find an antidote to the emptiness of existence. You have a clear and lively voice. Don't be such a defeatist!" (Allen, (2011), 1: 01:54). The antidote that Allen finds here is different from that in Klienman's story. Despite his talk about the importance of distractions, Allen has never stopped invoking the theme of death and meaninglessness in his films. If we take Gil to represent Allen's own position as an artist then it seems that while Allen wishes that he could completely fall into bad faith and inauthenticity, he cannot simply avoid coming back to reality as he truly understands it.

If Klienman is defeated by the harsh truths he faces, then Gil, in his way, proves victorious. Shadows and Fog is deliberately set at night-time, and this is suggestive of the kind of pessimism that Stein is arguing against. In contrast, the story in Midnight in Paris alternates between daytime and midnight which again is reflective of Gil's own mood changes. During the day, Gil is often disconnected from the people around him and is dissatisfied with life despite the beauty of the city. Paris is not fully alive for Gil during this midnight period, but when he enters the past, the city and its inhabitants become radiant for him, and he is charmed. The short magical travels to the past represent Gil's own escape from his anxiety over death and meaninglessness. Bad faith is not only tempting but proves to be delightful for Gil. The Paris of the past in this film is never shown during the day and Gil only experiences it at midnight. Hence, this aspect of the film further emphasizes the idea of night-time as representing the illusions that constitute bad faith and inauthenticity. Sartre and Heidegger would argue against Gil's actions here.

In his magical travels, Gil meets a young and beautiful woman by the name of Adriana whose predicament is similar to his. She too is unhappy with her present life and longs for the charms of Paris in the Belle Epoque era. While a romance grows between them, their relationship comes to a halt when Adriana finds a way, similar to Gil's, in the form of a magical carriage which takes her to her desired destination. She tries to convince Gil to stay with her permanently in this period only for him realize that this choice is not beneficial for him:

Adriana: Well, it's the present. It's dull.

Gil: Dull? It's not my present. I'm from 2010. 
Gil: I was trying to escape my present the same way you're trying to escape yours through a golden age.

$\ldots$

Gil: If you stay here though and this becomes your present, then pretty soon you'll start imagining another time was really your... you know, was really the golden time. Yeah that's, you know, what the present is. It's a little unsatisfying because life's a little unsatisfying.

...

Gil: This way I think, I think it's crazy. It doesn't really work. If I ever wanna write something worthwhile, I have to, you know, get rid of my illusions, and that I'll be happier in the past, is one of them. (Allen, (2011), 1:21:22)

Adriana becomes, in a way, a sounding board for Gil's thoughts and ideas here. This moment of clarity in the film is what drives him to alter his life. A key part here is that Gil, by travelling to the past and falling in love with Adriana, comes to realize that he will only be keeping himself in a state of chronic dissatisfaction if he were to choose fantasy over reality. The glamour and romanticism, he sees in the Paris of the 1920s, is a result of his own construction. From this moment on, he changes and while he still decides to make a permanent move to this city, he does so without the kind of fanciful projections he made earlier. The film ends with him strolling on a Parisian Street in midnight with the difference being that he no longer makes a magical journey into the past. Here, his bad faith and inauthenticity comes to an end, and he starts over his life with a new freshness and vigour. He finds the Heideggerian resoluteness he needs to reconcile himself with the facts of the meaninglessness of life and mortality.

\section{AN AMBIGUOUS POSITION}

If the above two films present two very different philosophical positions, then Allen (2014). through a film like Magic in the Moonlight, combines these two and present an even more ambiguous ending. In this film, Allen portrays a misanthropic magician by the name of Stanley who becomes a victim of a ruse conducted by his friend Howard with the assistance of a fake psychic named Sophie. As the film progresses, we find Stanley's pessimism slowly evaporating from his life when he unconsciously falls in love with Sophie. A séance is conducted in front of Stanley which shatters Stanley's scientific view of life and for a time he begins to revaluate his entire philosophical viewpoint on life and the afterlife. All of this leads to the following exchange towards the end of the story when Stanley realizes that he has been duped and confronts the masterminds behind the deception:

Stanley: Life's not fair Howard. In fact, as a general rule, as I've often said, it's pretty nasty. Because of Sophie, I began to succumb to magical thinking and for a while I was actually happy. But I was happy as a fool is happy. Happiness is not the natural human condition.

-..

Sophie: Well, I started reading that book by that German philosopher, you know, that you gave me? I didn't really understand much of it. But he said that we need our illusions to live.

Stanley: You mean lies. 
Sophie: You were much happier when you led some lies into your life Stanley.

$\cdots$

Stanley: We can't go around deluding ourselves.

Sophie: But we must if are we are to get through life. I mean, I didn't say it. I'm just quoting Mr...um...

Stanley: Nietzsche. (Allen, (2011), 1:15:13)

Although there is no specific work of Friedrich Nietzsche made here, one can infer that it could have been one of his earlier works like the Birth of Tragedy where Nietzsche (2000) argues that a person requires illusions to live in this world. The important point here is that Nietzsche (2000). would go on to abandon this idea in later works like Ecce Homo. Allen's position here is even more ambiguous when Stanley forgives Sophie and, in the end, they begin a genuine romantic relationship. Stanley clearly does not want to succumb to any type of magical thinking that would constitute bad faith. Sophie's inauthencity is contrasted to Stanley's desire for authenticity but one cannot be sure of which position Allen is advocating.

\section{CONCLUSION}

With the exception of Midnight in Paris, Shadows and Fog and Magic in the Moonlight have received mixed reactions from critics in general. In his review of Shadows and Fog, Matthew Lucas (2016). praises the visuals which were influenced by German Expressionism but points out that the film is rather lacking in substance. As this paper has shown, such a view of this film fails to see the hidden influence of the German philosopher Heidegger and how much of Klienman's story is devoted to the treatment of an important aspect of this philosopher's work. In his review of Magic in the Moonlight, Williams (2014). praises the cast and cinematography of the film, but like most reviewers, makes no attempt to praise the philosophical ambiguities the film presents. The critics are right in their respective assessments of these films especially when considering the cinematic aspects of these works. However, an interdisciplinary approach, where an analysis of Allen's manner of dramatizing certain intriguing existentialist philosophical ideas through the medium of cinema, allows for a deeper understanding of these films. This paper also shows both the debt Allen owes to the thinkers that have come before him as well as his ambivalent position with regards to the effects of their ideas. This paper also shows Allen's strength as a dramatist in the traditional sense of the word and his interweaving of philosophy and dramatic narrative makes him stand out, not just as a director, but also as a screenwriter whose narratives have a strong literary quality.

\section{REFERENCES}

Allen, (1992). Shadows and Fog (Film). Orion Pictures.

Allen, (2011). Midnight in Paris (Film). Gravier Productions, Mediapro, Televisio de Catalunya, Versatil Cinema.

Allen, (2014). Magic in the Moonlight. (Film). Perdido Productions, Gravier Productions.

Allen, W. (Director). (1989). Crimes and Misdemeanors (Film). Jack Rollins \& Charles H. Joffe Productions. 
Allen (16 May 2015). Irrational Man-conference- (en) Cannes 2015 (Video). YouTube.

Arlington, Edward Robinson. (2021, December 14). "Miniver Cheevy" Poetry Foundation.

Flynn, T. R. (2006). Existentialism : A Very Short Introduction. Oxford University Press. https://doi.org/10.1093/actrade/9780192804280.001.0001.

Heidegger, M. (2001). Being and Time. (J. Macquarrie and E. Robinson, Trans.) Blackwell. (1927).

Lee, S. H. (1997). Woody Allen's Angst : Philosophical Commentaries on His Serious Films. McFarland.

Lucas, M. (19, Feb 2016). From the Front Row.

Nietzsche, F. (2000). The Birth of Tragedy. (W. Kaufmann, Trans.) In Basic Writings of Friedrich Nietzsche. Modern Library. (1872).

Nietzsche, F. (2000). Ecce Homo. (W. Kaufmann, Trans.) In Basic Writings of Friedrich Nietzsche. Modern Library. (1908).

Reynolds, J. (2006). Understanding Existentialism. Acumen. https://doi.org/10.1017/UP09781844653690.

Sartre, J. P. (2003). Being and Nothingness. (H.E. Barnes, Trans). Routledge. (1943).

Williams, Craig. (17 Sep 2014). Cinevue. 